UDC 378.14.364

DOI: $10.31470 / 2415-3729-2018-8-214-224$

\title{
Pedagogical System of the Future Social Workers' Training for a Professional Mobility: Results of Experimental Work
}

\section{Hanna Ridkodubska}

Doctor of Philosophy in Pedagogy (Phd), Associate Professor

Associate Professor of the Department of Social Work and

Social Pedagogy

Khmelnytskyi National University,

$\triangle 11$, Instytutska Str., Khmelnytskyi, Ukraine, 29016

E-mail: anutabanditka1@ukr.net

ORCID: 0000-0003-0561-6835

\section{Педагогічна система підготовки до професійної мобільності майбутніх працівників соціальної сфери: результати дослідно-експериментальної роботи}

\section{Ганна Анатоліївна Рідкодубська}

кандидат педагогічних наук, доцент

доцент кафедри соціальної роботи і соціальної педагогіки

Хмельницький національний університет

вул. Інститутська, 11, м. Хмельницький, Україна, 29016

Дата надходження статті: 01 серпня 2018 р. Стаття прийнята до друку: 25 листопада 2018 р.

\section{Abstract}

The article is devoted to the pedagogical system of the future social workers' training for a professional mobility. The purpose of the article is to characterize the results of research and experimental work on the introduction of the pedagogical system of the future social workers' training for a professional mobility. 
The benefit of the study is that the theoretical and applied questions of implementing the pedagogical system of training future employees of the social sphere for a professional mobility are researched. The author has designed the appropriate model of this process and schematically shown it in the article.

The summarization and systematization of experimental data of the study has allowed determining the content of the pedagogical system of training for a professional mobility, which consists of three blocks: conceptual, technological and evaluative-productive. The conceptual block covered a social demand for social workers, the purpose of the pedagogical system (that was to train future social workers for a professional mobility), specific tasks, principles and methodological approaches to the future social workers' training for a professional mobility. The technological block combines a content provision of educational disciplines, technologies, methods and forms of the training. The evaluation-productive block presents components, criteria, levels and indicators of the future social workers' readiness for a professional mobility.

In the author's opinion, expanding the content of each block in training on a professional mobility will substantially enrich and refine the content of the future social workers' training. Moreover, disclosing the content of the experimental work on the future social workers' training for a professional mobility will improve the quality of their training under modern conditions.

Basing onto the results of the pedagogical experiment formative stage, the author has determined that the implementation of the author's pedagogical system of the future social workers' training for a professional mobility during the educational process at higher education institutions is effective, as the positive dynamics in the level of students' readiness for a professional mobility was revealed according to designed indicators, levels, components. The analysis of the results of the pedagogical experiment has also proved a high reliability of the received quantitative data.

Key words: social worker, professional mobility, pedagogical system of training for a professional mobility, research and experimental work. 


\section{References}

1. Lukashevych, M. P., Myhovych, I. I. (2002). Teoriia i metody sotsialnoi roboty [Theory and methods of social work]. Kyiv : MAUP [in Ukrainian].

2. Polishchuk, V. A. (2003). Profesiina pidhotovka fakhivtsiv sotsialnoi sfery: zarubizhnyi dosvid [Professional training of specialists in the social sphere: foreign experience]. Ternopil: Navchalna knyha Bohdan [in Ukrainian].

3. Ridkodubska, H. A. (2018). Diahnostyka hotovnosti do PM maibutnikh sotsialnykh pratsivnykiv [Diagnosis of readiness for the FP of future social workers]. Molodyi vchenyi - Young Scientist, (61), 64-68 [in Ukrainian].

4. Sushentseva, L. L. (2016). Profesiina mobilnist yak umova profesiinoho stanovlennia osobystosti $\mathrm{v}$ suchasnomu sotsiokulturnomu prostori [Professional Mobility as a Condition for the Professional Development of the Individual in Contemporary Socio-Cultural Space]. Suchasni informatsiini tekhnolohii ta innovatsiini metodyky navchannia $v$ pidhotovtsi fakhivtsiv: metodolohiia, teoriia, dosvid, problemy - Modern Informational Technologies and Innovative Methods in Professional Training: Methodology, Theory, Experience, Problems, 44, 95-100 [in Ukrainian].

5. Harchenko, S. Ya. (1999). Didakticheskie osnovyi podgotovki studentov $\mathrm{k}$ sotsIalno-pedagogicheskoy deyatelnosti [Didactic basics of preparing students for social and educational activities]. Lugansk : Alma mater [in Russian].

\section{Вступ}

Динамічний розвиток сучасного суспільства, поява нових технологій в усіх сферах життєдіяльності, швидкі темпи зміни орієнтирів, соціально-економічних умов професійного становлення, насамперед стосуються підготовки майбутніх фахівців. Тому перед вітчизняною вищою освітою стоїть завдання підготовки фахівців з високим рівнем відповідальності, позитивного ставлення до своєї роботи, стійкою психікою, вмотивованого та люблячого свою професію, професійно мобільного компетентного фахівця. 
Внесок у розробку питань підготовки до професійної мобільності та взаємодії майбутніх фахівців соціальної сфери в умовах постійної раціоналізації соціально-економічних умов функціонування суспільства зробили вітчизняні та зарубіжні вчені: П. Сорокін, Е. Зеєр, G. Andersson (Дж. Андерссон), P. Blau (П. Блау), J. Boddy (Дж. Бодді) та ін. Протягом останніх років до цієї проблеми звертались: Т. Гордеєва, Л. Горюнова, Н. Латуша, Л. Сушенцева, Р. Прима та ін.

Метою статті $€$ характеристика результатів дослідноекспериментальної роботи по впровадженню педагогічної системи підготовки до професійної мобільності майбутніх працівників соціальної сфери.

\section{Матеріал і методи дослідження}

Для досягнення поставленої мети у ході дослідження застосовано загальнонаукові методи аналізу, синтезу, порівняння та узагальнення наукових публікацій, моделювання, анкетування, тестування, опитування та ін.

\section{Результати та їх обговорення}

В розробленні системи підготовки до професійної мобільності в процесі організації дослідження ми спирались на вагомий внесок вітчизняних учених, у яких відображено погляди та ідеї щодо стратегії розвитку вищої педагогічної освіти, інноваційні процеси й реформи у вищій школі (І. Зязюн, I. Мельничук, Л. Романишина). професійно-педагогічної підготовки фахівців (Л. Александрова, О. Савченко, Л. Хомич, Л. Ядвіршис та ін.)

В нинішніх умовах підготовки майбутніх працівників соціальної сфери до професійної мобільності набуває нового змістового наповнення. Вважаємо, що для формування готовності до професійної мобільності майбутніх працівників соціальної сфери, стає важливим використання науково-виваженого механізму розробки та реалізації в освітній процес педагогічної системи підготовки до професійної мобільності майбутніх працівників соціальної сфери.

В науковій літературі «професійна мобільність» визначається інтегративним утворенням у цілісній структурі особистості працівника (Сушенцева, 2016:98). Своєрідність прояву готовності 
до професійної мобільності майбутніх працівників соціальної сфери зумовлено поліфункціональністю майбутніх працівників соціальної сфери та багатоаспектністю проблем, 3 якими звертаються клієнти та особливостями виконання професійних функцій (практичні ролі, посередницькі ролі, адміністративні ролі, дослідницькі ролі, сервісні ролі, тощо), що є передумовами позитивної динаміки процесів самоактуалізації та самореалізації. Специфічними ознаками готовності до професійної мобільності працівників соціальної сфери $€$ : клієнтоцентризм, природна схильність до інтеграції знань та врахування факторів процесу змін, швидкий перерозподіл внутрішніх резервів професійного розвитку, конструювання міжособистісних стосунків 3 різними типами клієнтів.

Розроблена нами педагогічна система підготовки до професійної мобільності майбутніх працівників соціальної сфери (рис. 1.) включала три взаємообумовлені блоки: концептуальний, технологічний та оцінно-результативний. Концептуальний блок охоплював соціальне замовлення на працівників соціальної сфери, мету педагогічної системи, яка полягала в підготовці до професійної мобільності майбутніх працівників соціальної сфери, завдання, специфічні принципи підготовки до професійної мобільності та методологічні підходи до підготовки до професійної мобільності майбутніх працівників соціальної сфери. Технологічний блок об'єднав змістове забезпечення навчальних дисциплін «Вступ до спеціальності», «Соціальна робота 3 дітьми. Сім'ями та молоддю», «Практикум з соціальної роботи», «Соціальна робота 3 різними групами клієнтів», «Соціальна реабілітація», Технології, методи та форми навчання. В оціннорезультативному блоці представлено компоненти, критерії, рівні та показники готовності до професійної мобільності майбутніх працівників соціальної сфери.

Реалізація педагогічної системи проводилась в декілька етапів. Дослідження проводилось у шести закладах вищої освіти, які представлено у таблиці 1.

На першому етапі завдання дослідно-експериментальної роботи полягало у аналізі наукової літератури, розробці наукового апарату дослідження та діагностиці готовності до 


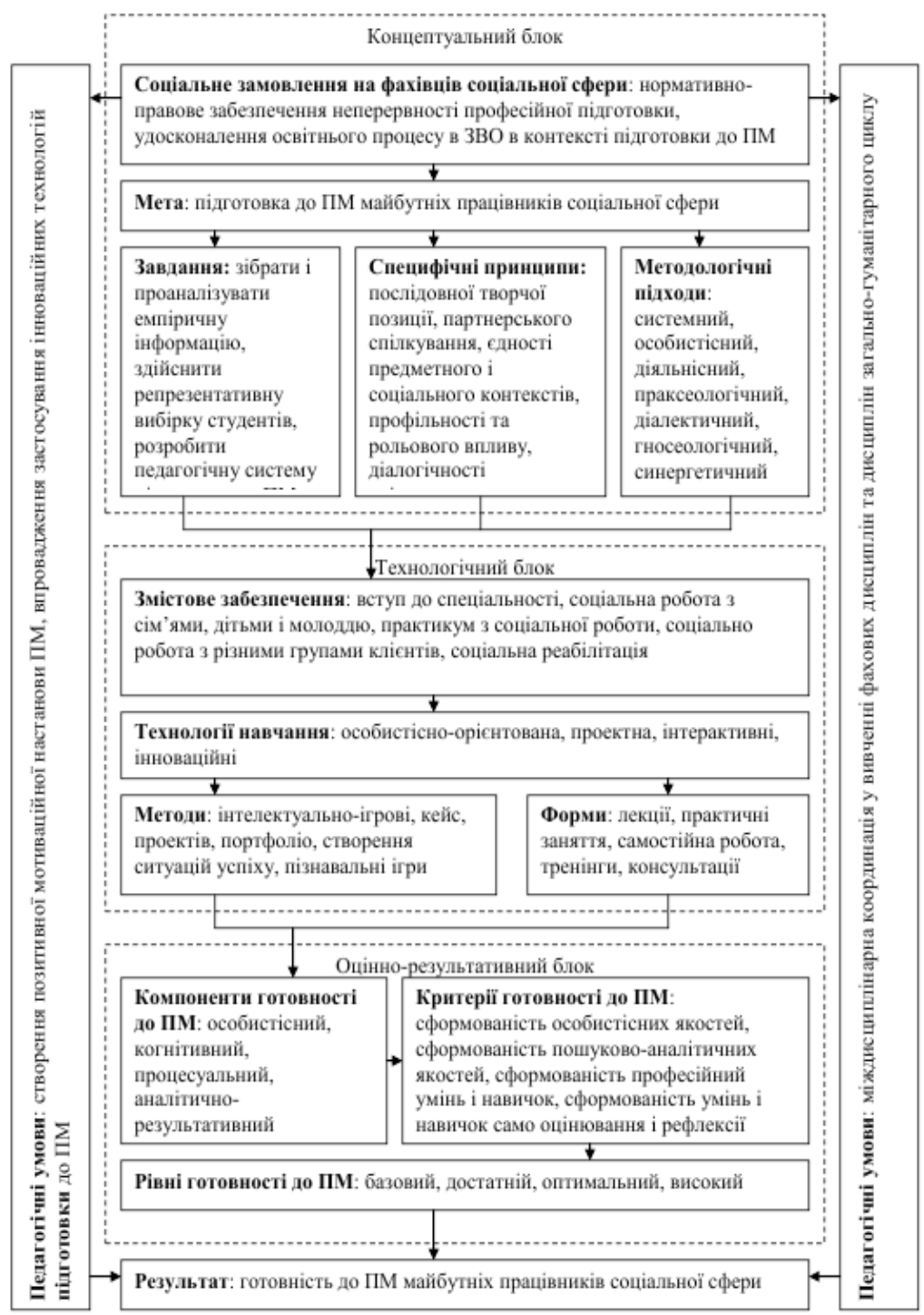

\section{Рис. 1. Модель педагогічної системи підготовки до професійної мобільності майбутніх працівників соціальної сфери}


професійної мобільності майбутніх працівників соціальної сфери (Рідкодубська, 2018), виділено показники та здійснено їх розподіл за компонентами (особистісний, когнітивний, процесуальноповедінковий, аналітико-результативний). За допомогою методологічного інструментарію з'ясовано рівень готовності до професійної мобільності майбутніх працівників соціальної сфери IV курсу закладів вищої освіти та зроблено висновок про те, що практично у третини студентів виявлено середній рівень готовності до професійної мобільності. Виходячи 3 аналізу результатів констатувального етапу педагогічного експерименту, підготовку до професійної мобільності майбутніх працівників соціальної сфери на формувальному етапі педагогічного експерименту здійснювали через реалізацію дослідно-експериментальної роботи, основними завданнями якої було визначено: розподіл на експериментальні та контрольні групи студенів, реалізація педагогічної системи підготовки до професійної мобільності та експериментальна перевірка їі дієвості. Реалізація підготовки до професійної мобільності майбутніх працівників соціальної сфери здійснена у розробленій і апробованій в процесі педагогічного дослідження педагогічній системі (Рідкодубська, 2018).

Таблиия 1.

\section{Заклади вищої освіти, які приймали участь у дослідно- експериментальній роботі.}

\begin{tabular}{|l|}
\hline \multicolumn{1}{|c|}{ Заклад вищої освіти } \\
\hline $\begin{array}{l}\text { 1. Кам'янець-Подільський національний університет імені Івана } \\
\text { Огієнка }\end{array}$ \\
\hline $\begin{array}{l}\text { 2. Центральноукраїнський державний педагогічний університет } \\
\text { імені Володимира Винниченка }\end{array}$ \\
\hline 3. Чернівецький національний університет імені Юрія Федьковича \\
\hline 4. Харківська гуманітарно-педагогічна академія \\
\hline 5. Хмельницький національний університет \\
\hline 6. Тернопільський національний економічний університет \\
\hline
\end{tabular}

Основною особливістю освітнього процесу студентів Експериментальних груп було постійне використання викладачами 
оновленого дидактичного наповнення дисциплін, включених у змістове наповнення технологічного блоку, що передбачало цілеспрямоване формування компонента готовності до професійної мобільності майбутніх працівників соціальної сфери. На основі результатів формувального етапу педагогічного експерименту (рис. 2.) ми визначили дієвість реалізації авторської педагогічної системи підготовки до професійної мобільності майбутніх працівників соціальної сфери в освітній процес закладів вищої освіти, адже показники сформованості готовності до професійної мобільності: на початку експерименту у 16,2\% студентів контрольних груп було виявлено високий рівень готовності, в кінці він складав 22,6\%. У студентів експериментальних груп на початку експерименту було виявлено $14,7 \%$ студентів із високим рівнем готовності до професійної мобільності, в кінці експериментальної роботи - у 31,3\% студентів.

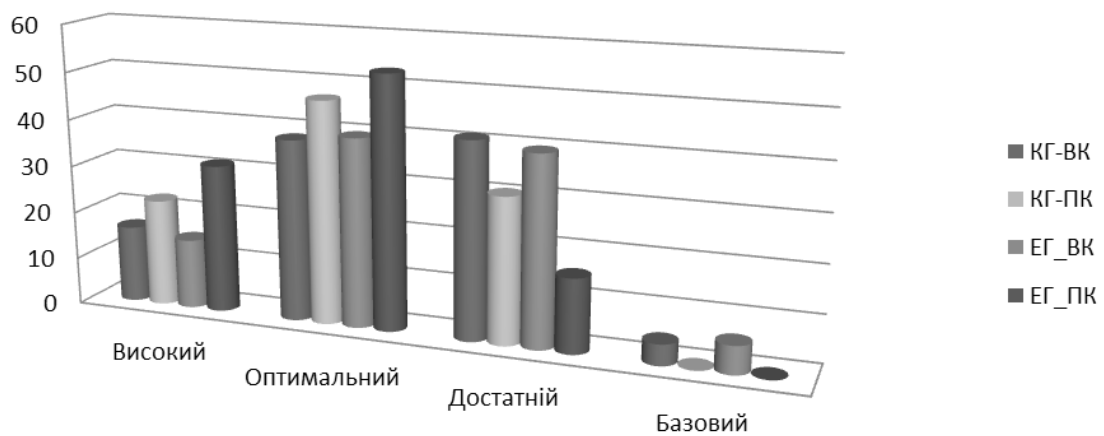

Оптимальний рівень готовності було виявлено у $38,2 \%$ студентів контрольних та 39,7\% експериментальних груп. Після реалізації педагогічної системи підготовки до професійної мобільності такий рівень було виявлено у 46,8\% контрольних та у 53,1\% експериментальних груп, різниця у показниках контрольних груп складає 8,6\%, в експериментальних - 13,4\%. Базовий рівень готовності на початку експериментальної роботи було виявлено у 4,4\% контрольних та 5,9\% експериментальних груп. Після закінчення реалізації педагогічної системи 
підготовки до професійної мобільності ні в контрольних, ні в експериментальних групах його не було виявлено. А, отже результативність запропонованої педагогічної системи підготовки до професійної мобільності наочно доведено.

\section{Висновки}

Аналіз результатів педагогічного експерименту з реалізації педагогічної системи підготовки до професійної мобільності майбутніх працівників соціальної сфери показав значний ріст рівня готовності до професійної мобільності за показниками, рівнями, компонентами та високу достовірність одержаних кількісних даних.

\section{Література}

1. Лукашевич М. П., Мигович I. I. Теорія і методи соціальної роботи: навч. посіб. Київ : МАУП, 2002. 136 с.

2. Поліщук В. А. Професійна підготовка фахівців соціальної сфери: зарубіжний досвід: посібник. Тернопіль: Навчальна книга - Богдан, 2003. 184 с.

3. Рідкодубська Г. А Діагностика готовності до ПМ майбутніх соціальних працівників. Молодий вчений. 2018. № 9 (61). С. 64-68

4. Сушенцева Л. Л. Професійна мобільність як умова професійного становлення особистості в сучасному соціокультурному просторі. Сучасні інформачійні технологіі та інновачійні методики навчання в підготовичі фахівців: методологія, теорія, досвід, проблеми: зб. наук. пр. Київ-Вінниця: ТОВ фірма «Планер», 2016. Вип. 44. С. 95-100.

5. Харченко С. Я. Дидактические основы подготовки студентов к соціально-педагогической деятельности. Луганск : Альма матер, 1999. 138 с.

Рідкодубська Г. А.

Педагогічна система підготовки до професійної мобільності майбутніх працівників соціальної сфери: результати дослідноекспериментальної роботи 


\section{Анотація}

Досліджено теоретико-прикладні питання реалізації педагогічної системи підготовки до професійної мобільності майбутніх працівників соціальної сфери. Узагальнення i систематизація експериментальних даних дослідження дозволили визначити зміст педагогічної системи підготовки до професійної мобільності, яка складається 3 трьох блоків: концептуального, технологічного та оцінно-результативного. Розширення змісту кожного $з$ блоків щодо підготовки до професійної мобільності суттєво збагатить і осучаснить змістове наповнення підготовки майбутніх працівників соціальної сфери. Крім того, розкриття змісту експериментальної роботи по підготовці до професійної мобільності майбутніх соціальних працівників дозволить підвищити якість їх професійної підготовки у сучасних умовах.

Ключові слова: працівник соціальної сфери, професійна мобільність, педагогічна система підготовки до професійної мобільності, дослідно-експериментальна робота.

\section{Ридкодубская А. А.}

\section{Педагогическая система подготовки к профессиональной мобильности будущих работников социальной сферы: результаты опытно-экспериментальной работы}

\section{Аннотация}

Исследованы теоретико-практические вопросы реализации педагогической системы подготовки к профессиональной мобильности будущих работников социальной сферы. Обобщение и систематизация экспериментальных данных исследования позволили определить содержание педагогической системы подготовки к профессиональной мобильности, которая состоит из трех блоков: концептуального, технологического и оценочнорезультативного. Расширение содержания каждого из блоков относительно подготовки к профессиональной мобильности существенно обогатит и осовременит смысловое наполнение подготовки будущих работников социальной сферы. Кроме того, 
раскрытие содержания экспериментальной работы по подготовке к профессиональной мобильности будущих социальных работников позволит повысить качество их профессиональной подготовки в современных условиях.

Ключевые слова: работник социальной сферы, профессиональная мобильность, педагогическая система подготовки к профессиональной мобильности, опытноэкспериментальная работа. 